\title{
Publicly-funded biobanks and networks in East Asia
}

\author{
Sunhee Lee ${ }^{1}$, Paul Eunil Jung ${ }^{1}$ and Yeonhee Lee ${ }^{1,2^{*}}$
}

\begin{abstract}
With the enactment of the Nagoya Protocol, international competitions to secure biological resources are intensifying. Biobanking is one of the many attempts to preserve biological resources and their information for the use in future research and development. Asian countries, especially China, Japan, and Korea are very active in biobanking activities under the strategic plans coordinated by their governments. They also proactively established networks for biobanks of Asia to facilitate resource and expertise sharing. Biobanks of these countries should furthermore standardize operating procedures and diversify funding sources for establishing stable operation systems.
\end{abstract}

\section{Background}

Since the adoption of the Convention on Biological Diversity (CBD) in 1992, biological resources have been increasingly considered as exclusive possessions of their originating countries rather than common assets of mankind. International competitions to secure bioresources have recently been overheated with the enactment of the Nagoya Protocol on access to genetic resources and benefit sharing (ABS) in 2014. According to the CBD provision, biological resources are genetic resources and organisms in parts or their entireties with actual or potential uses and values for mankind. They are more than simple collections of organisms-they are the source of academic and industrial advancement and exploitation.

Biobanking is one of the many attempts to conserve ecologically and scientifically valuable biological resources and their associated information for the advancement of life sciences. Biobanks both accept and provide viable (often culturable and replicable) organisms or their parts and information on their molecular and physiological characteristics. Since its first appearance in a scientific literature in 1990s (Hewitt and Watson 2013), the term "biobank" was often used narrowly to describe a

\footnotetext{
*Correspondence: yhlee@swu.ac.kr

${ }^{1}$ Korea National Research Resource Center (KNRRC), \#324, Golden 50 Commemoration Hall, Seoul Women's University, 621 Hwarang-ro, Nowon-gu, Seoul 01797, Korea

Full list of author information is available at the end of the article
}

repository of human specimens. As more scientists, policymakers, and other stakeholders of biobanks expanded the range of its definitions, the word now also accommodates non-human organisms, such as plants, animals, fungi, and bacteria. In recent online surveys, biobanking stakeholders concurred in including different organisms in the biobanking realm and further agreed that biobanks should follow standard operating procedures and distribute materials for scientific use (Hewitt and Watson 2013). Broader definitions of the term are also reflected in international guidelines and numerous national regulations, such as the guidelines of Organisation for Economic Cooperation and Development (OECD) and the laws of several European countries (Hewitt and Watson 2013).

Biobanking activities were recorded in Europe as early as 1890s (Day and Stacey 2008). Since then, numerous institutes were established in Europe and led the effort of conserving and distributing biological resources. For culture collections, European institutes outnumber the institutes of other continents by far in terms of volume and diversity of their collections. However, Japan, Korea, and China have recently seen a rapid increase in the new deposits. In terms of the numbers of new deposits, yearly aggregated amount of the three countries are comparable to the European aggregate (Smith et al. 2013).

In this paper, we observe the status of biobanks in Asian countries, with emphases on three East Asian countries, China, Japan, and Korea. Despite the recent rise of Asian countries in the biobanking field, lack of 
coordination may have precluded international scholars to identify and have access to Asian biobanks. Through this paper, we identify public biobanks of Asian countries and explain how they operate. Furthermore, we present major networks of Asia-Pacific biobanks and their functions.

\section{Biobanks by countries}

\section{Korea}

Prior to 1990, academic and clinical institutes in Korea primarily led the preservation efforts of biological resources. As worldwide interest in biological diversity and conservation heightened, the Korean government started to invest heavily in securing and utilizing biological resources for academic and industrial uses. In 1995, the Ministry of Science and Technology ${ }^{1}$ initiated a federal project to support and foster 5 research resource centers (RRCs; Lee and Lee 2009). This project has expanded to encompass 31 RRCs and 4 core centers, collectively managed by a central organization, Korea National Research Resource Center (KNRRC).

Korean public biobanks are operated by collaborative efforts of six government ministries (National Science and Technology Council Steering Committee 2015). Ministries collectively establish yearly plans for biological resource management, in order to prioritize policies for biological conservation, reduce risk factors in biological diversity, uphold sustainable use of ecosystem services, and strengthen international collaboration on conservation and research efforts. Under these joint objectives, each ministry has established responsible agencies to manage and support subordinate biobanks in accordance with their ministerial focus and interest.

Human biobanks are administered by the three ministries, the Ministry of Health and Welfare (MOHW), the Ministry of Food and Drug Safety (MFDS), and the Ministry of Science, ICT, and Future Planning (MSIP). Korea Centers for Disease Control and Prevention (KCDC), under the administration of $\mathrm{MOHW}$, launched the Korea Biobank Project (KBP) in 2008. Through this project, $\mathrm{KCDC}$ has planned to collect specimens from 200,000 patients and 300,000 general population (1st term, from 2008 to 2012) and to establish Korean Biobank Network for specimen distribution (2nd term, from 2013 to 2015; Cho et al. 2012). Until now, National Biobank of Korea (NBK), along with 17 regional biobanks of university hospitals and 2 network-affiliated hospitals, has accumulated human serum, plasma, DNA, and other specimens from 328,000 patients (as of December 2015). NBK also accommodates

${ }^{1}$ Currently the Ministry of Science, ICT, and Future Planning (MSIP). population-based specimens collected from 384,000 people as part of regional cohort studies (Centers for Disease Control \& Prevention, Korea 2016).

MSIP administers exceptionally diverse biobanks, unlike other ministries, in addition to the human biobanks. In accordance with the ministerial goal to foster scientific research (Ministry of Science, ICT and Future Planning 2015), three institutes, the Korea Research Institute of Bioscience and Biotechnology (KRIBB), the National Science Museum, and the Korea National Research Resource Center (KNRRC), endeavor to secure diverse research resources, including biological and non-biological resources. KRIBB manages 1 human biobank and 5 biobanks of other organisms, including animals, plants, and microbes (Korea Research Institute of Bioscience and Biotechnology 2014). The institute has set up the International Biological Material Research Center (IBMRC) for international research collaboration and collection of novel specimens. The National Science Museum houses 700,000 specimens of 9100 terrestrial and marine species (Korean Bio-resource Information System 2015). KNRRC accommodates 31 diverse biobanks of biological and non-biological research resources. The center has established best practice guidelines and integrated resource inventory system for biobanks to ensure the quality of resources and their information. Additionally, KNRRC hosts seminars and forums to educate biobank directors, staffs, and other biobanking stakeholders.

Other federal ministries handle more specialized biobanks, consistent with their ministerial responsibilities. Under the Ministry of Agriculture, Food, and Rural Affairs (MAFRA), the National Institute of Agricultural Sciences (NAS) and the National Institute of Animal Science (NIAS) support crops and livestock research and preservation implemented by laboratories of universities, local governments, and government-funded organizations. Korea Forest Service, another important agency of MAFRA, manages plant, insect, and microbial resources via National Institute of Forest Science (NIFoS), Korea Forest Seed and Variety Center (NFSV), and Korea National Arboretum (National Science and Technology Council Steering Committee 2015). Ministry of Oceans and Fisheries (MOF) appointed 14 laboratories of universities and research institutes as marine bioresource banks. Marine Biodiversity Institute of Korea was established in 2014 for public exhibition and preservation of marine organisms. The institute has collected more than 400,000 specimens which are as diverse as bacteria, fungi, algae, and vertebrates. Ministry of Environment (ME) operates the National Institute of Biological Resources (NIBR) for wildlife conservation and protection of endangered species. 
Federal ministries will continue the collaborative works for management of biological resources until 2020 as specified in the master plan laid out by the ministries in 2011. Table 1 lists publicly funded biobanks in Korea.
Japan

Japan has extensive specimen collections of diverse organisms which often have been managed by small-sized laboratories of academic or governmental institutes.

Table 1 Biobanks in Korea

\begin{tabular}{|c|c|c|}
\hline Name of institute & Website & Resources \\
\hline Korea National Research Resource Center (KNRRC) & www.knrrc.or.kr/english & Animal, plant, human-origin, microorganism \\
\hline $\begin{array}{l}\text { Korea Research Institute of bioscience \& Biotechnol- } \\
\text { ogy }\end{array}$ & www.kribb.re.kr/eng/sub02/sub02_05.jsp & Animal, plant, human-origin, microorganism \\
\hline Marine Biodiversity Institute of Korea & www.mabik.re.kr/html/en/ & Animal, plant, microorganism \\
\hline National Institute of Biological Resources & www.nibr.go.kr/eng & Plant, microorganism, vertebrata, insect specimen \\
\hline National Science Museum & www.science.go.kr/english/index.html & Animal, plant, DNA \\
\hline RDA-Genebank Information Center & www.genebank.go.kr/eng/ & $\begin{array}{l}\text { Plant germplasm, DNA, microorganism, sequence, } \\
\text { silkworm, insect }\end{array}$ \\
\hline \multicolumn{3}{|l|}{ Animal } \\
\hline Aging Tissue Bank & atb.knrrc.or.kr & Fresh frozen tissue, serum, animal model \\
\hline Animal Bio Resources Bank & www.abrb.or.kr & Animal secretion, physiologically active substance \\
\hline Arthropods of Medical Importance Resource Bank & amib.knrrc.or.kr & Animal extract, fresh frozen tissue, specimen, DNA \\
\hline Bovine Genome Resource Bank & bgrb.knrrc.or.kr & Paraffin block, serum, whole blood, DNA \\
\hline Korean Coral Resource Bank & www.coralbank.co.kr & cDNA library, DNA \\
\hline Laboratory Animal Resource Center & mouse.kribb.re.kr & Mouse, fertilized egg \\
\hline Marine Arthropod Depository Bank of Korea & www.madbk.org & Specimen \\
\hline Marine Echinoderm Resources Bank of Korea & merbk.syu.ac.kr/main.do & Specimen, sequence, DNA \\
\hline Marine Fish Resource Bank of Korea & cms.pknu.ac.kr/mfrbk & Specimen, DNA \\
\hline Marine Mollusk Resource Bank of Korea & www.mmrbk.org & Specimen, clone library, DNA \\
\hline National Primate Research Center & eng.primate.re.kr & Nucleic acid, tissue, cell, brain tissue \\
\hline $\begin{array}{l}\text { Neurogenic Laboratory \& Neuromarker Resource } \\
\text { Bank }\end{array}$ & www.brainprism.org & Specimen, protein, nucleic acids, BAC \\
\hline Parasite Resource Bank & www.parasite-bank.or.kr & Tissue, egg, specimen, DNA, serum \\
\hline Zebrafish Organogenesis Mutant Bank & zomb.knrrc.or.kr & Live animal, nucleic acids, sequence \\
\hline \multicolumn{3}{|l|}{ Microorganism } \\
\hline Bacteriophage Bank & www.phagebank.or.kr & Phage \\
\hline Center for Fungal Genetic Resources & genebank.snu.ac.kr & Fungi, DNA \\
\hline $\begin{array}{l}\text { Culture Collection of Antimicrobial Resistant } \\
\text { Microbes }\end{array}$ & www.ccarm.or.kr & Bacteria, fungi \\
\hline Culture Collection of Mushrooms & ccm.knrrc.or.kr & Fungal culture \\
\hline Extract Collection of Useful Microorganism & www.ecum.or.kr & Extract \\
\hline Helicobacter pylori Korean Type Culture Collection & hpktcc.knrrc.or.kr & Bacteria, clone, cell strains \\
\hline Korea Bank for Pathogenic Viruses & kbpv.knrrc.or.kr & Serum, virus \\
\hline Korea Environmental Microorganisms Bank & www.kbem.or.kr & Bacteria \\
\hline Korea Mushroom Resource Bank & kmrb.knrrc.or.kr & Fungal culture \\
\hline Korea Veterinary Culture Collection & kvcc.kahis.go.kr & Fungi, bacteria, virus, parasite, clone, serum \\
\hline Korean Collection for Oral Microbiology & kcom.knrrc.or.kr & Bacteria \\
\hline Korean Collection for Type Cultures & kctc.kribb.re.kr/English/index.aspx & Bacteria, fungi, microalgae, DNA \\
\hline Korean Lichen and Allied Bioresource center & kolabic.knrrc.or.kr & Fungi, microalgae, extract \\
\hline Marine \& Extreme Bioresources Collections & www.mebic.re.kr/mebic_l1/eng & Bacteria, algae, benthos \\
\hline Marine Fungal Resource Bank & mfrb.snu.ac.kr & Fungi, DNA \\
\hline Metagenome Resource Bank & mgrb.knrrc.or.kr & Sequence \\
\hline Mushroom bank & www.genebank.go.kr/pm_m/main.jsp & Specimen \\
\hline Myxobacteria Bank & myxobank.knrrc.or.kr & Myxobacteria \\
\hline National Culture Collection for Pathogens & nccp.cdc.go.kr & Pathogenic microorganism, DNA, RNA, plasmid, clone \\
\hline
\end{tabular}


Table 1 continued

\begin{tabular}{|c|c|c|}
\hline Name of institute & Website & Resources \\
\hline Plant Virus Genebank & www.virusbank.org & Virus, antibody, sequence \\
\hline Smart Microbial Carbohydrate lab & smclab.konkuk.ac.kr & Microbial carbohydrate \\
\hline Waterborne Virus Bank & www.wava.or.kr & Virus \\
\hline \multicolumn{3}{|l|}{ Plant } \\
\hline Brassica Resource Bank & brb.knrrc.or.kr & Seed \\
\hline Center for the Korea Potato Genetic Resources & kpgr.knrrc.or.kr & Plant, seed \\
\hline Ginseng bank & gb.knrrc.or.kr & Plant, plant extract, seed, cell line, DNA \\
\hline International Biological Material Research Center & www.ibmrc.re.kr & Plant \\
\hline Korea Bioactive Natural Material Bank & kbnmb.knrrc.or.kr & Plant, plant extract \\
\hline Korea Plant Extract Bank & extract.kribb.re.kr & Plant, plant extract \\
\hline Korea Seed \& Variety Service & www.seed.go.kr/english & Seed \\
\hline Korean Marine Plant Collection & www.kmpc.kr & Specimen, culture, DNA \\
\hline Marine Brown Algae Resources Bank & mbrb.chosun.ac.kr/main.do & Specimen, extract, culture, DNA \\
\hline Marine Green Algal Resources Bank & mgarb.pknu.ac.kr/main.do & Specimen, culture, DNA \\
\hline Medicinal Plant Resources Bank & mprb.knrrc.or.kr & Plant, extract, DNA \\
\hline National Forest Seed and Variety Center & www.kfsv.go.kr & Seed, clone, specimen \\
\hline National Institute of Agricultural Sciences & www.naas.go.kr/english & Plant, seed \\
\hline Plant DNA bank in Korea & pdbk.korea.ac.kr & DNA \\
\hline \multicolumn{3}{|l|}{ Human-origin } \\
\hline Human Serum Bank & hsb.knrrc.or.kr & Serum \\
\hline Korea Prostate Bank & www.prostatebank.or.kr & Tissue, plasma, serum, urine, DNA \\
\hline Korean Cell Line Bank & cellbank.snu.ac.kr/english & Cell line \\
\hline Korean Gynecologic Cancer bank & kgcb.or.kr & Serum, body fluid, cell line, tissue, plasma, saliva, urine \\
\hline Korean Human Gene Bank & genbank.kribb.re.kr & cDNA, gene set, library, clone \\
\hline Korean Leukemia Cell \& Gene Bank & www.klcgb.or.kr/eng & Cell line, DNA \\
\hline Liver Cancer Specimen Bank & lcsb.knrrc.or.kr & Tissue, plasma \\
\hline National Biobank of Korea & kbn.cdc.go.kr & Serum, plasma, urine, buffy coat, DNA \\
\hline $\begin{array}{l}\text { Seoul National University Hospital Biomedical } \\
\text { Research Institute }\end{array}$ & en.bri.snuh.org & $\begin{array}{l}\text { Serum, plasma, buffy coat, nucleic acid, B cell, urine, } \\
\text { lymphocytes, blood, tissue }\end{array}$ \\
\hline Wonkwang University Hospital & med.wku.ac.kr/?page_id=507 & Tissue, blood, DNA \\
\hline
\end{tabular}

The Japanese government has recently reorganized the management and funding scheme for biobanks as the government heavily emphasizes quality management of biological resources.

In 2015, the Cabinet Office of Japan established Japan Agency for Medical Research and Development (AMED) as a "control tower" for medical research and development (R\&D; Japan Agency for Medical Research and Development 2015). Previously, medical research in Japan was administered by three different ministries, Ministry of Education, Culture, Sports, Science and Technology (MEXT), Ministry of Health, Labour, and Welfare (MHLW), and Ministry of Economy, Trade and Industry (METI; Sano 2015). Each ministry had implemented different funding schemes which added burdens to medical researchers. As a part of the national revitalization strategy in 2013, the Cabinet acknowledged the importance of medical $R \& D$ and decided to create a "headquarters of healthcare policy," modeled after National Institutes of Health (NIH) of the United States (Hishiyama 2015; Japan Agency for Medical Research and Development 2015). This initiative was developed into the creation of AMED. While three ministries remain as key stakeholders, AMED now works as an integrated funding agency between researchers and ministries. The government anticipates that fast-tracked funding and clinical trial process will help researchers to engage more in research and develop novel treatments for Japanese population.

The Japanese government is currently interested in personalized treatments enabled by advance in genomic research. For collection of human specimens, MEXT and MHLW collaborate in managing human biobank networks of BioBank Japan (BBJ), National Center Biobank Network (NCBN), and Tohoku Medical Megabank 
Organization (ToMMo) biobank project (Furuta 2014). $\mathrm{BBJ}$ is a disease-oriented biobank which embarked in 2003 (Okamura et al. 2014). From its first cohort study (2003-2007), DNA, serum, and medical records of 200,000 patients were collected. RIKEN Center for Integrative Medical Sciences (IMS) and the Institute of Medical Science at the University of Tokyo (IMSUT) have teamed up for genomic analyses of specimens and data management. These institutes are securing additional DNA specimens and medical records from 100,000 patients of the second cohort (2013-2018). NCBN is also a network for disease-oriented biobanks, in collaboration of six centers specialized in different diseases, including cancer, neurology, cardiovascular diseases. While each center individually operates its own hospital and research institutes, they perform joint research through the shared platform among the centers. ToMMo biobank is a population-based institute, unlike the previous two networks, and created for the long-term study of people who suffered the 2011 Tohoku earthquake. With the support of the latest IT technology, this biobank aims to collect medical and genomic data of 150,000 individuals from 10,000 affected households with three generations (Matsui and Tashiro 2014).

National BioResource Project (NBRP) is an initiative managed by AMED for integrated and standardized management of biological resources (Nagai et al. 2015). Under the supervision of MEXT, the program commenced in 2002 to upgrade biobanking systems and facilities scattered throughout Japan. The program is at its third phase (2012-2016) of 5-year term and recently faced management transfer to AMED along with the opening of the agency. NBRP currently supports 29 facilities handling specimens and living organisms for scientific research. The project also emphasizes genome-enabled research to enhance the values of collected resources and specimen databases to better serve researchers.

For agricultural conservation efforts, Genebank Project has been implemented by the National Institute of Agrobiological Sciences (NIAS), under the supervision of the Ministry of Agriculture, Forestry and Fisheries (MAFF; National Institute of Agrobiological Sciences 2014; NIAS Genebank 2015). NIAS has accumulated 215,000 plant, 28,000 microbe, and 1000 animal accessions through the project and established online databases to provide their data to researchers. The project also aims to strengthen international cooperation and secure foreign genetic resources through exchange programs, joint research, and symposiums.

National Institute of Technology and Evaluation's Biological Resource Center (NBRC) of METI specializes in collection and preservation of microorganisms. NBRC provides services of domestic and international distributions and patent deposits and online databases for microbes with industrially useful properties (National Institute of Technology and Evaluation 2015b). The BRC also hosted the first meeting of Asian Consortium for the Conservation and Sustainable Use of Microbial Resources (ACM) and has strived to build cooperative relationships with other Asian countries (Asian Consortium For the Conservation and Sustainable Use of Microbial Resources 2015a; National Institute of Technology and Evaluation 2015a).

In summary, the Japanese government aims to strengthen life science research by the establishment of a dedicated funding agency and strategic support on biobanks handling useful resources for industrialization. Table 2 lists government-funded biobanks in Japan.

\section{China}

Human biobanking in China launched in 1994 with the establishment of immortalized cell lines from Chinese ethnic groups (Gan et al. 2015). As the Chinese government and academia saw growing importance of biological resources, biobanking activities in China have significantly expanded in the last decade. Disease-oriented biobanks are often affiliated with hospitals in major cities, like Beijing and Shanghai, and equipped with advanced medical equipment (Zhang et al. 2015). Beijing Biobank of Clinical Resources (BBCR) is composed of 14 hospitals and considered as the largest clinical biobank network in China. The project team of BBCR aims for diverse management, standardized operation, and thirdparty supervision (Wang et al. 2015). With accumulated expertise on biobanking operation, BBCR also provides frameworks for constructing new biobanks. Shanghai also has a well-established biobank project, called Shanghai Biobank Network (SBN). Currently, SBN consists of 18 allied institutes (Zhang et al. 2015) and preserves liver cancer tissue and rheumatism samples as key collections among other diverse specimens (Fan and Zhang 2011). Population-based biobanks in China collect specimens from various groups of population based on the unique objective of each biobank. The China Kadoorie Biobank (CKB) began in 2003 to collect medical data and blood samples from 510,000 individuals in 10 geographic regions for research on common chronic diseases among Chinese people. Other prominent population-based projects are the Guangzhou Biobank Cohort Study on elderly people and the Born in Guangzhou Cohort Study which will follow 1,000,000 pregnant women and their offspring for 20 years (Zhang et al. 2015).

Like the preceding two countries, genetic resources of livestock and crops are actively managed by the Ministry of Agriculture (MOA). Chinese Academy of Agricultural Sciences (CAAS) is a major institute organizing and 
Table 2 Biobanks in Japan

\begin{tabular}{|c|c|c|}
\hline Name of institute & Website & Resources \\
\hline BioResource Center, RIKEN & en.brc.riken.jp & Animal, microorganism, plant, human-origin \\
\hline DNA Bank, RIKEN BRCa & dna.brc.riken.jp & Human, mouse, S. pombe clones \\
\hline Japan Genetic Resources & www.shigen.nig.ac.jp/wgr/jgr/jgrUrlList.jsp & Animal, microorganism, plant \\
\hline National BioResource Project (NBRP) & www.nbrp.jp & Animal, microorganism, plant, human-origin \\
\hline National Institute of Genetics & www.nig.ac.jp/nig/ & Animal, microorganism, plant, human-origin \\
\hline NIAS Genebank & www.gene.affrc.go.jp & Animal, microorganism, plant, DNA \\
\hline \multicolumn{3}{|l|}{ Animal } \\
\hline Avian Bioscience Research Center ${ }^{a}$ & www.agr.nagoya-u.ac.jp/ nbrp/en/ & Chicken and quail: blood, egg, DNA \\
\hline Brain Science Institute, RIKEN ${ }^{a}$ & shigen.nig.ac.jp/zebra/ & Zebrafish \\
\hline C. elegans, Department of Physiology, TWMU ${ }^{a}$ & shigen.nig.ac.jp/c.elegans/ & Nematode \\
\hline ENU Mutants & ja.brc.riken.jp/lab/gsc/mouse & Mouse mutant \\
\hline Experimental Animal Division, RIKEN BRC ${ }^{a}$ & mus.brc.riken.jp/en/ & Mouse \\
\hline $\begin{array}{l}\text { Fly stocks of National Institute of Genetics (NIG- } \\
\text { FLY) }\end{array}$ & shigen.nig.ac.jp/fly/nigfly & Drosophila \\
\hline Institute of Laboratory Animals ${ }^{a}$ & www.anim.med.kyoto-u.ac.jp/nbr & Rat \\
\hline JCRB Laboratory Animal Resource Bank & animal.nibiohn.go.jp & Mouse \\
\hline KYORIN-Fly & shigen.nig.ac.jp/fly/kyorin/ & Drosophila \\
\hline Kyoto Stock Center DGGR & www.dgrc.kit.ac.jp & Drosophila \\
\hline $\begin{array}{l}\text { Medaka BioResource Unit, National Institute for } \\
\text { Basic Biology a }\end{array}$ & shigen.nig.ac.jp/medaka & Medaka \\
\hline Misaki Marine Biological Station & marinebio.nbrp.jp/oxycomanthus & Oxycomanthus japonicus \\
\hline Mouse Genetic Resources & shigen.nig.ac.jp/mouse/nig & Mouse \\
\hline National Institute for Physiological Sciences ${ }^{a}$ & nihonzaru.jp & Japanese macaque \\
\hline National Research Institute of Aquaculture & nria.fra.affrc.go.jp & Live animal, pathogen \\
\hline $\begin{array}{l}\text { Paramecium, Faculty of Science, Yamaguchi } \\
\text { University }^{\mathrm{a}}\end{array}$ & nbrpcms.nig.ac.jp/paramecium & Paramecium \\
\hline Shimoda Marine Research Center ${ }^{a}$ & marinebio.nbrp.jp/ciona & Ciona intestinalis \\
\hline $\begin{array}{l}\text { Silkworm, Faculty of Agriculture, Kyushu Uni- } \\
\text { versity }^{\mathrm{a}}\end{array}$ & silkworm.nbrp.jp & Silkworm \\
\hline Institute for Amphibian Biology ${ }^{a}$ & home.hiroshima-u.ac.jp/amphibia/xenobiores & Xenopus (tropical clawed frog) \\
\hline \multicolumn{3}{|l|}{ Microorganism } \\
\hline Bacillus subtillis, National Institute of Genetics ${ }^{a}$ & shigen.nig.ac.jp/bsub & Bacteria, clone \\
\hline $\begin{array}{l}\text { Cellular slime molds, Faculty of Life and Environ- } \\
\text { mental Sciences, University of Tsukuba }{ }^{a}\end{array}$ & nenkin.nbrp.jp & Slime mold, clone, DNA \\
\hline E. coli strain, National Institute of Genetics ${ }^{\mathrm{a}}$ & shigen.nig.ac.jp/ecoli/strain & Clone, plasmid, phage \\
\hline Japan Collection of Microorganisms, RIKEN BRC ${ }^{a}$ & jcm.brc.riken.jp & Microorganism \\
\hline JapoNet, National Institute of Genetics & night.nig.ac.jp/labs/MicroGen/japonet & Schizosaccharomyces japonicus yeast, plasmid \\
\hline $\begin{array}{l}\text { Microbial Culture Collection, National Institute } \\
\text { for Environmental Studies }\end{array}$ & mcc.nies.go.jp & Microorganism \\
\hline NITE Biological Resource Center & www.nite.go.jp/en/nbrc & Microorganism \\
\hline $\begin{array}{l}\text { Research Center for Pathogenic Fungi and } \\
\text { Microbial Toxicoses }{ }^{a}\end{array}$ & pathogenic.lab.nig.ac.jp & Pathogenic fungi, bacteria, protozoa \\
\hline Yeast Genetic Resource Center ${ }^{a}$ & yeast.lab.nig.ac.jp & Yeast, clone, plasmid, DNA \\
\hline \multicolumn{3}{|l|}{ Plant } \\
\hline $\begin{array}{l}\text { Algae, National Institute for Environmental } \\
\text { Studies }^{\text {a }}\end{array}$ & shigen.nig.ac.jp/algae & Algae culture, DNA \\
\hline Barley and Wild Plant Resource Center ${ }^{a}$ & shigen.nig.ac.jp/barley & Seed, DNA \\
\hline $\begin{array}{l}\text { Chrysanthemum, Laboratory of Plant Chromo- } \\
\text { some and Gene Stock, Hiroshima University }\end{array}$ & shigen.nig.ac.jp/chrysanthemum & Seed \\
\hline Experimental Plant Division, RIKEN BRC & epd.brc.riken.jp/en/ & Arabiodopsis: cultured cell, seed, gene \\
\hline Frontier Science Research Center ${ }^{a}$ & www.legumebase.brc.miyazaki-u.ac.jp & $\begin{array}{l}\text { Lotus japonicus, Glycine max/soja: seed, vector, } \\
\text { DNA; bacteria }\end{array}$ \\
\hline
\end{tabular}


Table 2 continued

\begin{tabular}{|c|c|c|}
\hline Name of institute & Website & Resources \\
\hline $\begin{array}{l}\text { Komugi, Laboratory of Genetics, Kyoto Univer- } \\
\text { sity }^{a}\end{array}$ & shigen.nig.ac.jp/wheat/komugi & Wheat: seed, microarray, DNA \\
\hline $\begin{array}{l}\text { Morning Glory, Faculty of Science, Kyushu } \\
\text { University }{ }^{a}\end{array}$ & shigen.nig.ac.jp/asagao & Seed, DNA \\
\hline Oryzabase, National Institute of Genetics ${ }^{a}$ & shigen.nig.ac.jp/rice/oryzabase & Rice: wild and mutant strain \\
\hline Tohoku Univ. Brassica Seed Bank & $\begin{array}{l}\text { www.agri.tohoku.ac.jp/pbreed/Seed_Stock_DB/ } \\
\text { Stock_English_top.html }\end{array}$ & Seed \\
\hline Tomato, Gene Research Center ${ }^{a}$ & tomato.nbrp.jp & Plant, DNA \\
\hline \multicolumn{3}{|l|}{ Human-origin } \\
\hline BioBank Japan & biobankjp.org & Serum, DNA \\
\hline Cell Engineering Division - Cell Bank, RIKEN BRC ${ }^{a}$ & cell.brc.riken.jp/en/ & General, iPS, and stem cell line \\
\hline Institute for Frontier Medical Sciences ${ }^{a}$ & shigen.nig.ac.jp/escell/human & Embryonic stem cell \\
\hline Institute of Medical Science ${ }^{a}$ & www.ims.u-tokyo.ac.jp/imsut/en/ & Human cord blood stem cells \\
\hline National Center Biobank Network & www.ncbiobank.org & Tissue, iPS cell, serum, plasma, PBMC, DNA \\
\hline $\begin{array}{l}\text { Tohoku Medical Megabank Organization } \\
\text { (ToMMo) biobank }\end{array}$ & megabank.tohoku.ac.jp/english/ & $\begin{array}{l}\text { Serum, plasma, buffy coat, PBMC, urine, saliva, } \\
\text { breast milk, DNA }\end{array}$ \\
\hline
\end{tabular}

a Biobanks funded by the third phase of the National BioResource Project (NBRP). Some institutes, such as RIKEN BRC, have assumed numerous NBRP projects but they are listed separately as each project has a clear organizational structure and hosts its own website

conducting agricultural research under the supervision of MOA. The Chinese central government has guaranteed financial support of CAAS under the Agricultural Science and Technology Innovation Program (ASTIP; American Association for the Advancement of Science 2013). The dedicated funding helps the institute continues on long-term preservation of agricultural resources and conducts rigorous research. CAAS is running a longterm nationwide biobank of plant germplasms and 10 medium-term plant biobanks.

The Ministry of Environment Protection (MEP) is mainly focused on maintaining biological diversity and protecting endemic and endangered species of China. The ministry endeavors to protect diverse organisms through a number of institutes, including the Southwest China Germplasm Bank of Wild Species (The Ministry of Environmental Protection of China 2014). This bank preserves plant seeds of 10,000 species, animal germplasms, macrofungi, and microorganisms. In addition, Chinese academic institutes now explore the cryopreservation option for cell lines of wild animals, such as Bengal tigers (Guan et al. 2010) and pandas (Yu et al. 2015).

The Ministry of Science and Technology (MOST) has established the National Science and Technology Infrastructure (NSTI) to raise research capacity by effective management of research resources (Ministry of Science and Technology of the People's Republic of China 2006). NSTI aims to create a science and technology "infrastructure platform" which consolidates management system for effective use and sharing of biological resources and for prevention of wasted funding due to duplicated or unnecessary financial support. Under this project, an open database of biological resources in China is under development for improved sharing of resources and data (Xu 2007). One of the NSTI divisions is the National Infrastructure of Microbial Resources (NIMR) which collectively manages nine microbial resource centers. Each biobank has different characteristics and research emphasis as shown in their collections, either subjectspecific (e.g. agricultural, medical, or pharmaceutical) or site-specific (e.g. marine-oriented). China General Microbiological Culture Collection Center (CGMCC) is one of the NSTI-supported biobanks geared toward more general and comprehensive collections of microorganisms and managed by the Institute of Microbiology at Chinese Academy of Science (IMCAS).

In order to create an integrated and open platform for effective management of biological resources, the Chinese government created China National Genebank (CNGB). The Genebank consists of bioresource bank, bioinformatics database, and consortium system (Zhang et al. 2015). Bioinformatics data are stored in cloud for various applications, such as healthcare and germplasm preservation (China National Genebank 2015). CNGB also engages in developing and providing standard operation procedures and training personnel for biobanking skills. The Genebank aspire to present a new biobanking model for the Chinese science communities and industries. Table 3 summarizes Chinese biobanks funded by the government. 
Table 3 Biobanks in China

\begin{tabular}{|c|c|c|}
\hline Name of institute & Website & Resources \\
\hline China Center for Type Culture Collection & www.cctcc.org & Fungi, bacteria, algae, plant and animal cell line, virus \\
\hline China Germplasm Bank of Wild Species & www.genobank.org & $\begin{array}{l}\text { Fungi, seed, plant and animal germplasm, microorganism, } \\
\text { DNA }\end{array}$ \\
\hline China National GeneBank (CNGB) & www.nationalgenebank.org/en/ & $\begin{array}{l}\text { Animal, plant, microorganism, human-origin, metagen- } \\
\text { ome data }\end{array}$ \\
\hline \multicolumn{3}{|l|}{ Animal and plant } \\
\hline Chinese Academy of Agricultural Sciences (CAAS) & www.caas.cn & Livestock and crop germplasm \\
\hline Institute of Botany, Chinese Academy of Sciences & english.ib.cas.cn & Plant specimen, seed, fossil sample \\
\hline Institute of Hydrobiology, Chinese Academy of Sciences & english.ihb.cas.cn & Aquatic organism, algae culture \\
\hline China Zebrafish Resource Center & zfish.cn & Zebrafish \\
\hline National Infrastructure of Fishery Germplasm Resources & zzzy.fishinfo.cn & Specimen, cell, sperm, DNA \\
\hline \multicolumn{3}{|l|}{ Microorganism } \\
\hline Agricultural Culture Collection of China & www.accc.org.cn & Fungi, plant pathogen \\
\hline China Center for Industrial Culture Collection & www.china-cicc.org & Fungi, bacteria \\
\hline China Forestry Culture Collection Center & www.cfcc-caf.org.cn & Fungi, bacteria, virus \\
\hline China General Microbiological Culture Collection Center & www.cgmcc.net & Bacteria \\
\hline China Pharmaceutical Culture Collection & www.cpcc.ac.cn & Fungi, bacteria, virus \\
\hline China Veterinary Culture Collection Center & www.cvec.org.cn & Bacteria \\
\hline $\begin{array}{l}\text { Institute of Microbiology, Chinese Academy of Sciences } \\
\text { (IMCAS) }\end{array}$ & www.im.cas.cn & Fungi, virus, strain \\
\hline Marine Culture Collection of China & www.mccc.org.cn & Fungi, bacteria \\
\hline National Center for Medical Culture Collections & www.cmccb.org.cn & Bacteria \\
\hline $\begin{array}{l}\text { Wuhan Institute Of Virology, Chinese academy of Sci- } \\
\text { ences }\end{array}$ & english.whiov.cas.cn & General and pathogenic virus \\
\hline \multicolumn{3}{|l|}{ Human-origin ${ }^{a}$} \\
\hline Beijing Biobank of Clinical Resource & www.beijingbiobank.cn & Cell line, DNA \\
\hline China Kadoorie Biobank & www.ckbiobank.org & Blood \\
\hline China Marrow Donor Program & www.cmdp.com.cn & Blood \\
\hline Clinical Oncology Institute, Beijing Cancer Hospital & www.bjcancer.org & Tumor tissue, blood \\
\hline $\begin{array}{l}\text { Eastern Hepatobiliary Surgery Hospital, the Second } \\
\text { Military Medical University of Chinese PLA }\end{array}$ & www.ehbh.cn & Tissue, blood, urine, nucleic acid \\
\hline Eighth Hospital of Wuhan City & www.wh8yy.cn & Tissue, blood, plasma, serum, fluid, nucleic acid, protein \\
\hline Fudan-Taizhou Institute of Health Sciences & - & DNA \\
\hline Guangxi Zhuang Autonomous Region Tumour Hopstial & www.gxhospital.com & Tissue, serum, plasma, lymphocyte \\
\hline Jiangsu Province Hospital & www.jsph.net & Tumor tissue, blood \\
\hline Renji Hospital, Shanghai Jiao Tong University & www.renji.com & Serum, plasma, tissue and DNA \\
\hline Sixth Affiliated Hospital of Sun Yat-sen University & www.zs6y.com & Tissue, serum, plasma, blood cells, blood, feces \\
\hline Sun Yat-sen University Cancer Center & www.sysucc.org.cn & Blood, serum, plasma, cell, nucleic acid \\
\hline Taizhou Hospital of Zhejiang Province & www.tzhospital.com & Tissue, blood, serum, plasma, cerebrospinal fluid \\
\hline The Fifth People's Hospital of Shanghai & www.5thhospital.com & Blood, urine \\
\hline The First Affiliated Hospital of Xinjiang Medical University & www.xydyfy.cn & Tumor tissue, blood \\
\hline The Key Laboratory of Xinjiang Endemic, Ethnic Disease & - & Blood \\
\hline Tianjin Medical University Cancer Institute \& Hospital & www.tjmuch.com & Tumor tissue, blood \\
\hline Tissue Bank of Fudan University Shanghai Cancer Center & www.shca.org.cn & Tissue \\
\hline Tongji Hospital & www.tjh.com.cn & Tissue, blood, cell, DNA \\
\hline West China Hospital & www.cd120.com & Tissue, blood \\
\hline $\begin{array}{l}\text { Wuxi No. } 4 \text { People's Hospital (Affiliated Hospital of Jiang- } \\
\text { nan University) }\end{array}$ & www.wuxihospital.com & $\begin{array}{l}\text { Tissue, RNA, serum, plasma, lymphocyte, stem cell and } \\
\text { cell line }\end{array}$ \\
\hline Zhejiang Cancer Hospital & www.zchospital.com & Tissue, tumor, serum, plasma, white blood cell layer \\
\hline
\end{tabular}

a The list of human-origin biobanks is adopted from Cheng et al. (2013) 
Other Asian biobanks and Asian biobank networks Biobanks of other Asian countries are also in active operations. Most Asian countries have nationally funded culture collections available to international scholars. Some countries, such as Taiwan and Malaysia have populationbased biobanking projects established to understand common and chronic diseases of their citizens. Table 4 is the partial list of Asian biobanks in Asia-Pacific.

As numerous definitions of biobanks point out resource sharing as one of their key functions (Organisation for Economic Co-operation Development 2012; Hewitt and Watson 2013), networking is seemingly an indispensable element for most of the biobanks. Biobanks can improve their institutes and others by sharing their resources, data, and expertise through domestic and international networks. Generally, domestic biobanking networks in
Asia are created or supported by governmental agencies for integrated management of specific resources, efficient funding, and support for research based on these resources. International networks are often more comprehensive in terms of resource types and aim for research cooperation at national-level. As domestic networks were described in previous section, we will focus on international networks in this section (Table 5).

Asian Network of Research Resource Centers (ANRRC) is a well-established network of Asian and Oceanian biological and non-biological resource centers. In 2009, the first meeting of ANRRC was held in Korea. Since then, the network grew to include 103 centers from 14 countries (Lee et al. 2016). Through the network, members share biobanking expertise and scientific technology and open the prospect for collaboration. The 2015 annual

Table 4 Biobanks in Asia-Pacific

\begin{tabular}{|c|c|c|c|}
\hline Country & Name of institute & Website & Resources \\
\hline \multicolumn{4}{|c|}{ Animal and plant } \\
\hline India & National Bureau of Plant Genetic Resources & www.nbpgr.ernet.in & Plant genetic Resource \\
\hline \multirow[t]{3}{*}{ Taiwan } & National Museum of Marine Biology and Aquarium & www.nmmba.gov.tw/english & Animal and algae specimen \\
\hline & National Plant Genetic Resources Center & www.npgrc.tari.gov.tw & Crop germplasm \\
\hline & World Vegetable Center & avrdc.org & Seed \\
\hline Thailand & Siriraj House Dust Mite Center for Services and Research & www.dustmitethailand.com & Dust mite \\
\hline Vietnam & Institute of Ecology and Biological Resources & www.iebr.ac.vn/index.asp?prgID=100 & Animal and plant specimen \\
\hline \multicolumn{4}{|c|}{ Microorganism } \\
\hline Indonesia & Indonesian Center for Biodiversity and Biotechnology & icbb.or.id & Microorganism for plant \\
\hline Malaysia & Malaysian Agriculture Research and Development Institute & www.mardi.gov.my & Bacteria, fungi, plant seed \\
\hline Philippines & $\begin{array}{l}\text { Microbiological Research and Services Laboratory Culture } \\
\text { Collection, University of the Philippines-Diliman (UPCC) }\end{array}$ & nsri.upd.edu.ph/main/?page_id=140 & Fungi and bacteria \\
\hline Taiwan & Bioresource Collection and Research Center & www.bcrc.firdi.org.tw & Fungi and bacteria \\
\hline \multirow[t]{5}{*}{ Thailand } & Thailand Network on Culture Collection & www1a.biotec.or.th/TNCC & \\
\hline & Thailand Bioresource Research Center (TBRC) & www.tbrcnetwork.org & Fungi \\
\hline & Department of Medical Sciences Thailand Culture Collection & engweb.dmsc.moph.go.th & Human pathogenic microorganism \\
\hline & $\begin{array}{l}\text { Plant Pathology and Microbiology Division, Department of } \\
\text { Agriculture }\end{array}$ & www.doa.go.th/en/ & Plant pathogenic microorganism \\
\hline & Thailand Institute of Scientific and Technological Research & www.tistr.or.th/tistreng/ & Industrial microorganism \\
\hline Vietnam & Vietnam Type Culture Collection & vtcc.imbt.vnu.edu.vn & Fungi and bacteria \\
\hline \multicolumn{4}{|c|}{ Human-origin } \\
\hline \multirow[t]{2}{*}{ Australia } & Australasian Biospecimen Network Association & www.abna.org.au & Tumor \\
\hline & Australian Breast Cancer Tissue Bank & www.abctb.org.au & Breast cancer tissue \\
\hline \multirow[t]{2}{*}{ India } & ICMR National Tumor Tissue Repository, Tata Memorial Centre & tmc.gov.in & Tumor bone, blood, tissue \\
\hline & $\begin{array}{l}\text { Rajiv Gandhi Cancer Institute \& Research Centre (RGCI \& RC) } \\
\text { Biorepository }\end{array}$ & www.rgcirc.org & Blood \\
\hline Malaysia & The Malaysian Cohort & mycohort.gov.my & Blood, urine \\
\hline \multirow[t]{3}{*}{ Singapore } & NUH Tissue Repository & medicine.nus.edu.sg/tissue/ & Blood, body fluid, tissue \\
\hline & Clinical Trials Resource Centre, Singapore General Hospital & www.sgh.com.sg & Tissue \\
\hline & SingHealth Tissue Repository & research.singhealth.com.sg & Tissue, serum \\
\hline Taiwan & Taiwan Biobank & www.twbiobank.org.tw & Blood, urine, DNA, plasma \\
\hline Thailand & Tissue Repository of Chulabhorn Hospital & www.cccthai.org/l-eng/ & Tissue \\
\hline
\end{tabular}


Table 5 Biobank networks in Asia

\begin{tabular}{lll}
\hline Network name & Acronym & Homepage \\
\hline Asian Network of Research Resource Centers & ANRRC & www.anrrc.org \\
ASEAN Centre for Biodiversity & ACB & www.aseanbiodiversity.org \\
Asian Consortium for the Conservation and Sustainable Use of Microbial Resources & ACM & www.acm-mrc.asia \\
Asian Biological Resource Center Network & ABRCN & www.abrcn.net \\
\hline
\end{tabular}

meeting had a session dedicated to the standardization of biobanks to generate discussions and draw a consensus among Asian biobanking stakeholders.

For cooperation of Asian microbiological biobanks, Asian Consortium for the Conservation and Sustainable Use of Microbial Resources (ACM) is established in 2004. ACM has members from 13 Asian countries, including China, India, Indonesia, Japan, and Korea (Asian Consortium For the Conservation and Sustainable Use of Microbial Resources 2015b). In order to bolster international research collaboration, ACM encourages the establishment of proper microbial resource centers and provides training for preservation techniques and taxonomy of microorganisms (Asian Consortium For the Conservation and Sustainable Use of Microbial Resources 2010; Korean Collection for Type Cultures 2015). In addition, Asian Biological Resource Center Network (ABRCN) was organized for the establishment of database for sharing resources among ACM members (Asian Biological Resource Center Network 2015).

\section{Conclusion}

Biobanking is the fundamental scientific effort to preserve and manage biological resources rapidly dissipating from the planet. In this paper, we have observed public biobanks of Asian countries, especially ones in China, Japan, and Korea. These biobanks are characterized by strategic operations orchestrated and assessed by their governments. Asian biobanks are also active in creating and utilizing networks for domestic and international collaboration. Recently, these three countries have enthusiastically partaken in the establishment of the International Standard for biobanks by TC 276 Biotechnology of the International Organization for Standardization (ISO).

In general, East Asian biobanks are heavily influenced by visions and plans of the governments as their financial resource is often solely dependent on governmental funding. Such fiscal system allows stable funding, however only for the defined period of time. Biobanks of Asia must consider diversifying funding sources by adding values to biological resources and offering additional services, such as data analyses, trainings, and software development as suggested by the OECD guideline for biological resource centers. Biobanks of Korea, Japan, and China have seen rapid growth in size over the last decade thanks to the substantial investment from governments. Now these countries should further focus on establishing stable and systematic resource centers and providing end-users with high-quality resources processed in compliance to international standards.

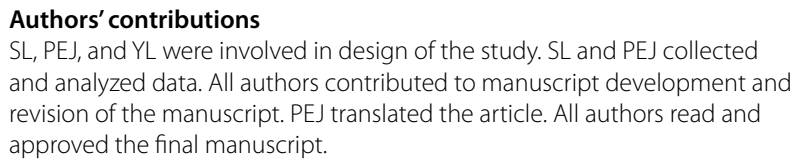

\section{Author details}

${ }^{1}$ Korea National Research Resource Center (KNRRC), \#324, Golden 50 Commemoration Hall, Seoul Women's University, 621 Hwarang-ro, Nowon-gu, Seoul 01797, Korea. ${ }^{2}$ Department of Horticulture, Biotechnology and Landscape Architecture, Seoul Women's University, 621 Hwarang-ro, Nowon-gu, Seoul 01797, Korea.

\section{Acknowledgements}

This study is supported by the Ministry of Science, ICT, and Future Planning and the National Research Foundation of Korea (NRF-2015M3A9B8028468).

\section{Competing interests}

The authors declare that they have no competing interests.

\section{Notice of republication}

This paper is first published in Korean in the Journal of Standards and Standardization under the title,"A Study on Publicly-Funded Biobanks in the Northeast Asia and Standardization Trends of Biological Resource" in volume 5 issue 2 (2015). The paper was translated and updated by PEJ.

Received: 20 January 2016 Accepted: 30 June 2016

Published online: 15 July 2016

\section{References}

American Association for the Advancement of Science (2013) The Chinese Academy of Agricultural Sciences: envisioning an innovative future. Science 340(6136):1122. doi:10.1126/science.340.6136.1122-c

Asian Biological Resource Center Network (2015) About us. http://www.abrcn. net/aboutus.html. Accessed 1 Oct 2015

Asian Consortium for the Conservation and Sustainable Use of Microbial Resources (2010) Kazusa statement. http://www.acm-mrc.asia/kazusastatement.html. Accessed 1 Oct 2015

Asian Consortium for the Conservation and Sustainable Use of Microbial Resources (2015a) Activities. http://www.acm-mrc.asia/activities.htm. Accessed 21 Dec 2015

Asian Consortium for the Conservation and Sustainable Use of Microbial Resources (2015b) List of ACM member organizations. http://www.acmmrc.asia/members.html. Accessed 1 Oct 2015

Centers for Disease Control \& Prevention, Korea (2016) 2015 Annual Report on National Biobank of Korea 
Cheng LE, Shi C, Wang X, Li Q, Wan Q, Yan Z, Zhang Y (2013) Chinese biobanks: present and future. Genet Res 95:157-164. doi:10.1017/ S0016672313000190

China National Genebank (2015) Introduction. http://cngb.org/genebank. jhtml. Accessed 23 Dec 2015

Cho SY, Hong EJ, Nam JM, Han B, Chu C, Park O (2012) Opening of the National Biobank of Korea as the Infrastructure of Future Biomedical Science in Korea. Osong Public Health Res Perspect 3(3):177-184. doi:10.1016/j. phrp.2012.07.004

Day J, Stacey G (2008) Biobanking. Mol Biotechnol 40(2):202-213. doi:10.1007/ s12033-008-9099-7

Fan JL, Zhang J (2011) Shanghai Biobank Network (SBN). Biopreserv Biobank 9(2):133. doi:10.1089/bio.2011.9211

Furuta K (2014) Biobanking in Japan: an overview and look to the future. ISBER News 14(3):4-5

Gan R, Wang H, Song Y, Fan J, Xiong Y (2015) Chinese biobanking initiatives. Biopreserv Biobank 13(1):4-7. doi:10.1089/bio.2014.0096

Guan WJ, Liu CQ, Li CY, Liu D, Zhang WX, Ma YH (2010) Establishment and cryopreservation of a fibroblast cell line derived from Bengal Tiger (Panthera tigris tigris). Cryoletters 31(2):130-138

Hewitt R, Watson P (2013) Defining Biobank. Biopreserv Biobank 11(5):309_ 315. doi:10.1089/bio.2013.0042

Hishiyama Y (2015) Research and development policy on regenerative medicine in Japan. Paper presented at the Japan-UK regenerative medicine research symposium, London, 8 September 2015

Japan Agency for Medical Research and Development (2015) Overview. http:// www.amed.go.jp/en/aboutus/gaiyou.html. Accessed 10 Dec 2015

Korea Research Institute of Bioscience and Biotechnology (2014) KRIBB Annual Report 2014

Korean Bio-resource Information System (2015) Resource statistics by institute. http://www.kobis.re.kr/. Accessed 8 Dec 2015

Korean Collection for Type Cultures (2015) International training course on microbial taxonomy: introduction. http://kctc.kribb.re.kr/_OPEN/acm/ ACM_Intro.aspx. Accessed 23 Dec 2015

Lee D, Lee Y (2009) The Korea National Research Resource Center. Biopreserv Biobank 7(3):137-142. doi:10.1089/bio.2009.0007

Lee S, Nam S, Jung PE, Kim K-J, Lee Y (2016) Asian Network of Research Resource Centers. Biopreserv Biobank. doi:10.1089/bio.2016.0008

Matsui K, Tashiro S (2014) Ethical challenges for the design and conduct of mega-biobanking from Great East Japan Earthquake victims. BMC Med Ethics 15(1):1-9. doi:10.1186/1472-6939-15-55

Ministry of Science, ICT and Future Planning (2015) Vison \& strategies. http:// english.msip.go.kr/english/msipContents/contents.do?mld=Mjg5. Accessed 19 Aug 2015

Ministry of Science and Technology of the People's Republic of China (2006) National Science and Technology Infrastructure Program. http:// www.most.gov.cn/eng/programmes1/200610/t20061008_36200.htm. Accessed 20 Oct 2015

Nagai H, Sato K, Fujimaki H, Suto M (2015) Introduction to National BioResource Project (NBRP) in Japan. Japan

National Institute of Agrobiological Sciences (2014) National Institute of Agrobiological Sciences, Japan

National Institute of Technology and Evaluation (2015a) Bilateral relation with Asian Nations. http://www.nite.go.jp/en/nbrc/global/asia/about_egron. html. Accessed 21 Dec 2015

National Institute of Technology and Evaluation (2015b) Biological Resource Center, NITE (NBRC). http://www.nite.go.jp/en/nbrc/index.html. Accessed 21 Dec 2015

National Science and Technology Council Steering Committee (2015) Action plan for management of bio-resources for research, Korea

NIAS Genebank (2015) Information on Plant Genetic Resources (PGR) Asia symposium. https://www.gene.affrc.go.jp/event-ws_20151221.php. Accessed 21 Dec 2015

Okamura N, Kubo M, Miyano S (2014) New initiative for the implementation of Genomic Medicine in Japan. Paper presented at the Genomic Medicine Centers Meeting Vl: Global Leaders in Genomic Medicine, Washington, DC, 8 January 2014

Organisation for Economic Co-operation Development (2012) OECD best practice guidelines for biological resource centres. OECD Publishing, Paris

Sano T (2015) About AMED. Paper presented at the 2015 Bio Future Forum, Seoul, 30 November 2015

Smith D, Fritze D, Stackebrandt E (2013) Public service collections and biological resource centers of microorganisms. In: Rosenberg E, DeLong E, Lory $\mathrm{S}$, Stackebrandt E, Thompson F (eds) The prokaryotes. Springer, Berlin, pp 267-304. doi:10.1007/978-3-642-30194-0_14

The Ministry of Environmental Protection of China (2014) China's Fifth National Report on the Implementation of the Convention on Biological Diversity

Wang X, Ni M, Wang P, Li H (2015) BBCR-largest biobank network in China. Biopreserv Biobank 13(3):A-2

Xu G-H (2007) Open access to scientific data: promoting science and innovation. Data Sci J 6:OD21-OD25. doi:10.2481/dsj.6.OD21

Yu F-J, Zeng C-J, Zhang Y, Wang C-D, Xiong T-Y, Fang S-G, Zhang H-M (2015) Establishment and cryopreservation of a Giant Panda skeletal musclederived cell line. Biopreserv Biobank 13(3):195-199. doi:10.1089/ bio.2014.0073

Zhang Y, Li Q, Wang X, Zhou X (2015) China biobanking. In: Karimi-Busheri F (ed) Biobanking in the 21 st century. Springer, Berlin, pp 125-140

\section{Submit your manuscript to a SpringerOpen ${ }^{\odot}$ journal and benefit from:}

- Convenient online submission

- Rigorous peer review

- Immediate publication on acceptance

- Open access: articles freely available online

- High visibility within the field

- Retaining the copyright to your article

Submit your next manuscript at springeropen.com 